\title{
Kompetensi Pedagogik Guru dalam Melaksanakan Standar Proses Kurikulum PAI 2013 Edisi Revisi di SMK PGRI Pekanbaru
}

\author{
Devita $^{1^{*}}$, Gusma Afriani ${ }^{2}$ \\ ${ }^{1,2}$ Program Studi Pendidikan Agama Islam, Universitas Islam Negeri Sultan Syarif Kasim Riau
}

\begin{tabular}{l}
\hline \multicolumn{1}{c}{ INFO ARTIKEL } \\
\hline Riwayat Artikel: \\
Diterima: $30-10-2020$ \\
Disetujui: $01-11-2020$ \\
Diterbitkan: $01-11-2020$
\end{tabular}

Kata kunci:

Kompetensi Paedagogik

Standar Proses

Kurikulum 2013

Pendidikan Agama Islam

\begin{abstract}
ABSTRAK
Abstract: This research is motivated by the implementation of the Revised Edition 2013 PAI Curriculum Process Standard which is still relatively low. Therefore, this study aims to: 1) determine the pedagogical competence of teachers in implementing the Revised Edition 2013 PAI Curriculum Process Standards at SMK PGRI Pekanbaru; and 2) knowing the factors that affect the pedagogical competence of teachers in implementing the Revised Edition 2013 PAI Curriculum Process Standards at SMK PGRI Pekanbaru. This type of research is a descriptive research conducted at SMK PGRI Pekanbaru. The population in this study were 1 teacher in the field of Islamic Religious Education, namely, Mr. Farizal., S.Ag., at SMK PGRI Pekanbaru. In this study, researchers took a saturated sampling technique. The data collection techniques used were observation, questionnaires, tests, and documentation. The data collected was then analyzed using SPSS version 18.00 for Windows. Based on the results of this study, it can be concluded that the pedagogical competence of teachers in implementing the Revised Edition 2013 PAI Curriculum Process Standards at SMK PGRI Pekanbaru is classified as "Good". The factors that affect the pedagogical competence of teachers in implementing the Revised Edition of the 2013 PAI Curriculum Process Standards are: 1) teacher educational background; 2) teachers' experiences in teaching; 3) teacher health; 4) teacher income; 5) educational facilities; 6) discipline in work; and 7) school supervision.
\end{abstract}

Abstrak: Penelitian ini dilatarbelakangi oleh pelaksanaan Standar Proses Kurikulum PAI 2013 Edisi Revisi masih tergolong rendah. Oleh karena itu, penelitian ini bertujuan untuk: 1) mengetahui kompetensi pedagogik guru dalam melaksanakan Standar Proses kurikulum PAI 2013 Edisi Revisi di SMK PGRI Pekanbaru; dan 2) mengetahui faktor-faktor yang mempengaruhi kompetensi pedagogik guru dalam melaksanakan Standar Proses Kurikulum PAI 2013 Edisi Revisi di SMK PGRI Pekanbaru. Jenis penelitian yang digunakan adalah penelitian deskriptif yang dilaksanakan di SMK PGRI Pekanbaru. Populasi dalam penelitian ini adalah guru bidang studi Pendidikan Agama Islam yang berjumlah 1 orang guru yaitu, bapak, Farizal., S.Ag., di SMK PGRI Pekanbaru. Dalam penelitian ini, peneliti mengambil teknik sampling jenuh. Teknik pengumpulan data yang digunakan adalah observasi, angket, tes, dan dokumentasi. Data yang dikumpulkan kemudian dianalisis menggunakan SPSS versi 18.00 for Windows. Berdasarkan hasil penelitian ini dapat disimpulkan bahwa kompetensi pedagogik guru dalam melaksanakan Standar Proses kurikulum PAI 2013 Edisi Revisi di SMK PGRI Pekanbaru tergolong "Baik". Adapun faktor-faktor yang mempengaruhi kompetensi pedagogik guru dalam melaksanakan Standar Proses kurikulum PAI 2013 Edisi Revisi adalah: 1) latar belakang pendidikan guru; 2) pengalaman guru dalam mengajar; 3) kesehatan guru; 4) penghasilan guru; 5) sarana pendidikan; 6) disiplin dalam bekerja; dan 7) pengawasan sekolah.

\footnotetext{
Alamat Korespondensi:

Gusma Afriani

Program Studi Pendidikan Agama Islam

Universitas Islam Negeri Sultan Syarif Kasim Riau, Pekanbaru

E-mail: gusma.afriani@uin-suska.ac.id
} 


\section{LATAR BELAKANG}

Guru memiliki peran yang sangat strategis bahkan sebagai ujung tombak dalam menentukan keberhasilan suatu program pendidikan, karena seorang guru merupakan orang yang bersinggungan langsung dengan peserta didik. Kedudukan seorang guru dibandingkan dengan unsur-unsur lainnya dalam pendidikan sangatlah dominan, karena betapapun bagusnya sebuah metode dan kurikulum yang tersusun rapi, tetapi semua itu akan bermuara pada sosok guru, untuk itu guru harus menjadi sosok yang profesional. Dalam Undang-undang no 14 tahun 2005 tentang guru dan dosen, bahwa yang dimaksud dengan guru adalah: "Pendidik profesional yang memiliki tugas utama mendidik, mengajar, membimbing, mengarahkan, melatih, menilai dan mengevaluasi peserta didik pada pendidikan anak usia dini, jalur pendidikan formal, pendidikan dasar dan pendidikan menengah (Rochman, 2012). Selain itu, guru adalah pendidik yang menjadi tokoh, panutan, dan identifikator bagi peserta didik dan lingkungannya. Oleh karena itu, guru harus memiliki standar kualitas tertentu, yang mencakup tanggung jawab, wibawa, mandiri, dan disiplin (Mulyasa, 2007). Perlu dipahami bahwa, untuk menjadi seorang guru yang profesional harus memiliki beberapa standar kompetensi, salah satunya adalah kompetensi pedagogik. Hal ini sebagaimana diatur oleh peraturan pemerintah Republik Indonesia no. 74 tahun 2008 tentang guru. Kompetensi pedagogik bisa dikatakan sebagai ruh dari seorang guru karena kompetensi inilah yang menjadi pembeda dan profesi-profesi lainnya.

Kompetensi pedagogik sendiri adalah kemampuan mengola pembelajaran peserta didik yang meliputi, pemahaman terhadap peserta didik, perancangan dan pelaksanaan pembelajaran, evaluasi hasil belajar dan pengembangan peserta didik untuk mengaktualisasikan berbagai potensi yang di miikinya (Standar Nasional Pendidikan penjelasan pasal 28 ayat 3 butir a (Priansa, 2014). Keberhasilan kurikulum sebagian besar terletak ditangan guru, selaku pelaksana kurikulum. Para guru bertanggung jawab sepenuhnya dalam pelaksanaan kurikulum, baik secara keseluruhan maupun sebagai tugas berupa penyampaian bidang studi atau mata pelajaran yang sesuai dengan program yang dirancang kurikulum. Untuk itu, guru harus berusaha agar penyampaian bahanbahan pembelajaran itu dapat berhasil secara maksimal, dan oleh karena itu pula guru dituntut untuk memahami kurikulum secara baik.

Berkenaan dengan pelaksanaan kurikulum, seorang guru harus mampu mengembangkan kurikulum berdasarkan tingkat satuan pendidikannya masing-masing yang disesuaikan dengan kebutuhan lokal. Kurikulum yang sekarang ini dianggap pemerintah mampu menjadi pandangan baru dalam fokus acuan pendidikan adalah kurikulum 2013. Berbeda dengan kurikulum sebelumnya, kurikulum 2013 dalam perencanaan pelaksanaannya, di-klaim dapat memberikan solusi bagi terkendalanya kemajuan bangsa indonesia melalui guruan karakter yang memiliki pendekatan ilmiah (scientific approach) sehingga output pendidikan yang dihasilkan akan sesuai dengan harapan. Pelaksanaan kurikulum ini diharapkan dapat menghasilkan insan yang produktif, kreatif, dan inovatif. Hal ini dimungkinkan, karena kurikulum ini berbasis karakter dan kompetensi, yang secara konseptual memiliki beberapa keunggulan. Tahun 2013 perubahan kurikulum kembali untuk SD, SMP, SMA, dan SMK.

Kemudian pada tahun 2015 dilakukan Revisi kurikulum 2013 (K-13) dan konsekuensinya perubahan dilakukan berdasarkan berbagai masukan dan publik, para ahli dan para pegiat serta pemerhati pendidikan sehingga ada perbaikan pada format dan isinya. Perbaikan kurikulum 2013 ini dengan diawali adanya diklat kurikulum yang dilaksanakan menjelang berakhirnya semester genap tahun pelajaran 2015/2016, di mana dalam pelaksanaannya peserta pelatihan ini dipilih dari guru-guru Kemendikbud yang dalam pelaksanaannya UKG (Uji Kompetensi Guru) memperoleh hasil yang memuaskan. Kurikulum 2013 untuk tahun 2017 terjadi revisi lagi. Revisi K13 Tahun 2017 tidak terlalu signifikan namun perubahan difokuskan untuk meningkatkan hubungan atau keterkaitan antara kompetensi inti (KI) dan kometensi dasar (KD). Sedangkan dalam penyusunan Rencana Pelaksanaan Pembelajaran (RPP) K13 revisi tahun 2017, yang dibuat harus muncul empat macam hal yaitu; PPK, Literasi, 4C, HOTS sehingga perlu kreatifitas guru 
dalam meramunya. Jadi, perubahan kurikulum pendidikan merupakan salah satu tuntutan yang mau tidak mau harus tetap dilakukan dan tinggal penetapan tentang waktu saja (Kurniasih, 2014). Pengembangan kurikulum 2013 yang beragam mengatur pada standar nasional pendidikan untuk meminjam pencapaian tujuan pendidikan nasional. Standar nasional pendidikan terdiri atas standar kompetensi kelulusan, standar isi, standar proses, standar pendidik dan tenaga kependidikan, standar sarana dan prasarana, standar pengelolaan pendidikan, standar pembiayaan pendidikan dan standar penilaian pendidikan (Purwati \& Amri, 2013).

Perubahan yang dihasilkan adalah menjadi manusia seutuhnya. Dengan demikian, tujuan pendidikan nasional perlu dijabarkan menjadi himpunan kompetensi dalam tiga ranah kompetensi tersebut. Di dalamnya terdapat sejumlah kompetensi yang harus dimiliki seseorang, agar dapat menjadi orang beriman dan bertakwa, berilmu. Kompetensi-kompetensi ini sebagai pegangan bagi pendidik, bahwa dalam mengajarkan mata pelajaran yang diajarkan, ada pesanpesan sosial dan spiritual (Abduhzen, 2013). Ditinjau dari standar proses, sasaran pembelajaran dalam kurikulum 2013 Edisi Revisi mencakup rana sikap, keterampilan dan pengetahuan yang di elaborasi untuk setiap satuan pendidikan. Oleh karena itu, proses pembelajaran yang semula terfokus pada eksplorasi, elaborasi dan konfirmasi difokuskan pada pembinaan sikap, keterampilan dan pengetahuan melalui penerapan model pembelajaran yang tepat. Sejalan dengan kenyataan tersebut, belajar tidak hanya terjadi di dalam ruang kelas, tetapi juga dilingkungan sekolah dan masyarakat. Oleh karena itu, dalam pembelajaran yang mengimplementasikan kurikulum 2013 Edisi Revisi, guru bukan satu-satunya sumber belajar. Pada dimensi sikap, sikap tidak diajarkan secara verbal, tetapi melalui contoh, pembiasaan aktivitas, dan teladan (Abidin, 2014).

SMK PGRI Pekanbaru merupakan salah satu sekolah yang sudah menerapkan kurikulum 2013 Edisi Revisi. Terkait dengan sistem Kurikulum 2013 Edisi Revisi yang melakukan beberapa persiapan untuk melaksanakan Kurikulum 2013 Edisi Revisi. Hal ini bisa di lihat dari sarana prasarana, fasilitas dan sumber belajar yang mendukung. Berdasarkan observasi yang peneliti lakukan selama PPL di SMK PGRI Pekanbaru, sejauh ini guru selalu melakukan usaha mempersiapkan halhal yang terkait dengan pelaksanaan Kurikulum 2013 Edisi Revisi. Seperti diklat-diklat kurikulum, strategi untuk mengembangkan peserta didik dan lain sebagainya. Walaupun guru telah melaksanakan kurikulum 2013 Edisi Revisi sesuai dengan kompetensi pedagogik yakni kemampuan mengelola pembelajaran peserta didik yang meliputi pemahaman terhadap peserta didik, perancangan dan pelaksanaan pembelajaran, evaluasi hasil belajar serta pengembangan peserta didik untuk mengaktualisasikan berbagai potensi yang dimilikinya (Priansa, 2014). Namun pada kenyataannya, Pelaksanaan Standar Proses Kurikulum PAI 2013 Edisi Revisi masih tergolong rendah. Hal ini dapat dilihat dari gejala-gejala yang ditemukan sebagai berikut: 1) masih ada proses pembelajaran yang belum berjalan sesuai dengan apa yang ditetapkan oleh kurikulum PAI 2013 Edisi Revisi; 2) masih ada peserta didik yang kurang aktif dalam pembelajaran; 3) masih ada peserta didik yang tidak memahami materi pelajaran; 4) masih ada peserta didik yang tidak mengerjakan tugas; dan 5) masih ada peserta didik yang tidak mau berfikir dan mencari solusi.

Beberapa usaha yang dilakukan adalah mendeteksi Pelaksanaan Standar Proses Kurikulum 2013 Edisi Revisi. Oleh karena itu, peneliti tertarik ingin meningkatkan Kompetensi Pedagogik Guru dengan melakukan deteksi awal pada pola berpikir dalam suatu penelitian dengan judul

"Kompetensi Pedagogik Guru dalam Melaksanakan Standar Proses Kurikulum PAI 2013 Edisi Revisi di SMK PGRI Pekanbaru".

\section{METODE}

Jenis penelitian yang digunakan dalam artikel ini adalah penelitian deskriptif yang dilaksanakan di SMK PGRI Pekanbaru. Pemilihan lokasi ini di dasarkan atas pertimbangan bahwa persoalan yang akan diteliti ada di lokasi ini. Selain dari itu dari segi pertimbangan waktu dan biaya, lokasi penelitian ini dapat penulis jangkau sehingga peneliti dapat melakukan penelitian di 
lokasi tersebut. Sedangkan untuk waktu penelitian ini akan di laksanakan dari bulan Juni hingga Agustus 2020. Populasi dalam penelitian ini adalah guru bidang studi Pendidikan Agama Islam yang berjumlah 1 orang guru yaitu, bapak, Farizal., S.Ag., di SMK PGRI Pekanbaru. Dalam penelitian ini, peneliti mengambil teknik sampling jenuh. Teknik sampling jenuh adalah teknik penentuan sampel bila semua anggota populasi digunakan sebagai sampel. Hal ini sering dilakukan bila jumlah populasi relative kecil, kurang dari 30 orang, atau penelitian yang ingin membuat generalisasi dengan kesalahan yang sangat kecil. Istilah lain sampel jenuh adalah sensus, dimana semua anggota populasi dijadikan sampel. Jadi sampel dalam penelitian ini adalah seluruh anggota populasi yaitu 1 (satu) orang guru Pendidikan Agama Islam. Dalam penelitian ini, peneliti menggunakan teknik pengumpulan data yaitu: observasi, tes, angket, dan dokumentasi. Teknik analisis data yang digunakan dalam penelitian ini adalah teknik deskriptif kuantitatif dengan persentase menggunakan bantuan SPSS versi 18.00 for Windows.

\section{HASIL DAN PEMBAHASAN}

\section{Analisis Data Angket Kompetensi Pedagogik Guru Dalam Melaksanakan Standar Proses Kurikulum PAI 2013 Edisi Revisi di SMK PGRI Pekanbaru}

Sebagaimana disajikan sebelumnya, bahwa teknik analisis data ini deskriptif kuantitatif dengan persentase. Sesuai dengan ketentuan yang peneliti tetapkan bahwa kompetensi pedagogik guru dalam melaksanakan standar proses kurikulum PAI 2013 Edisi Revisi dapat digolongkan menjadi lima golongan yaitu: Tidak Pernah, Jarang, Kadang-kadang diberi, Sering, Selalu. Sedangkan persentase dari kelima kategori tersebut adalah sebagai berikut:

Pertama, 81\%-100\% kompetensi pedagogik guru dalam melaksanakan standar proses kurikulum PAI 2013 Edisi Revisi dikategorikan sangat baik.

Kedua, 61\%-80\% kompetensi pedagogik guru dalam melaksanakan standar proses kurikulum PAI 2013 Edisi Revisi dikategorikan baik.

Ketiga, 41\%-60\% kompetensi pedagogik guru dalam melaksanakan standar proses kurikulum PAI 2013 Edisi Revisi dikategorikan cukup baik.

Keempat, 21\%-40\% kompetensi pedagogik guru dalam melaksanakan standar proses kurikulum PAI 2013 Edisi Revisi dikategorikan kurang baik, dan

Kelima, 0. 20\% kompetensi pedagogik guru dalam melaksanakan standar proses kurikulum PAI 2013 Edisi Revisi dikategorikan sangat tidak baik.

Berdasarkan analisis data diperoleh informasi bahwa persentase hasil dari angket yang peneliti lakukan tentang kompetensi pedagogik guru dalam melaksanakan standar proses Kurikulum PAI 2013 Edisi Revisi adalah $(100:(5 \times 25) \times 100 \%)=80 \% .100$ adalah jumlah skor, 5 merupakan nilai skor tertinggi, 25 adalah jumlah peryataan atau pertanyaan pada responden/guru, dan $100 \%$ adalah bilangan tetap. Berdasarkan hasil analisis data tersebut dapat diketahui persentase dari kompetensi padagogik guru dalam melaksanakan standar proses kurikulum PAI 2013 di SMK PGRI Pekanbaru yakni $80 \%$. Persentase ini berada pada kategori "Baik". Karena rata-rata persentasenya diperoleh sebesar 80\% berada diantara 61\%-80\%. Dengan demikian, dapat ditarik kesimpulan bahwa kompetensi pedagogik guru dalam Melaksanaan standar proses kurikulum PAI 2013 Edisi Revisi di SMK PGRI Pekanbaru dikategorikan "Baik".

\section{Analisis Data Tes Objektive tentang Kompetensi Pedagogik Guru Dalam Melaksanakan Standar Proses Kurikulum PAI 2013 Edisi Revisi di SMK PGRI}

Berdasarkan data yang di dapat dari hasil tes objektif kepada guru Pendidikan Agama Islam di SMK PGRI Pekanbaru adalah, dari 15 butir soal yang di ujikan yang benar hanya 12 butir soal. Hasil analisis menunjukkan bahwa objektifitas kompetensi paedagogik berada pada kategori "Baik" karena angka persentase yang di peroleh berada diantara 61\%-80\%. Berdasarkan kategori yang ditentukan diatas, disimpulkan bahwa kompetensi pedagogik guru dalam melaksanakan standar proses kurikulum PAI 2013 Edisi Revisi di SMK PGRI Pekanbaru tergolong "Baik". 


\section{Faktor yang Mempengaruhi Kompetensi Pedagogik Guru dalam Melaksanakan Standar Proses Kurikulum PAI 2013 Edisi Revisi Di SMK PGRI Pekanbaru}

Menurut teori pendidikan bahwa faktor yang bisa mempengaruhi kompetensi pedagogik guru ada tujuh, yaitu: Latar belakang pendidikannya, pengalamannya dalam mengajar, kesehatan, penghasilannya, sarana pendidikan sekolah, disiplin dalam menjalankan tugas, pengawasan sekolah. Berdasarkan wawancara peneliti dengan bapak Drs. Shofrudin. AS selaku Kepala Sekolah SMK PGRI Pekanbaru tentang kompetensi pedagogik guru sebagai berikut:

"Farizal, S. Ag., adalah salah satu guru di SMK PGRI Pekanbaru yang mengampu matapelajaran Pendidikan Agama Islam di kelas X XI dan XII. Ia sudah sangat baik dalam mengajar dan selalu ada peningkatan. Menurut beliau Bapak Farizal, S.Ag telah memenuhi faktor-faktor yang mempengaruhi kompetensi pedagogik guru".

Latar belakang pendidikan bapak Farizal, S.Ag., adalah SD di Labuhan Tanjak, SMP 1 Air Haji, SMA 1 Ranah Pesisir, dan S1 di UIR Fakultas Agama. Bapak Farizal, S.Ag., mengajar di SMK PGRI Pekanbaru mulai dari tahun 2005 pada matapelajaran Pendidikan Agama Islam.

Selama mengajar disini tidak ada mengalami sakit berat, hanya penyakit ringan saja seperti demam, batuk dan lain-lain. Dia adalah guru yang sangat disiplin dalam menjalankan tugasnya sebagai pengajar dan ahli dibidangnya yaitu sebagai guru Pendidikan Agama Islam. Di SMK PGRI Pekanbaru semua aktifitas yang dilakukan guru dan siswa tidak lepas dari pengawasan kepala sekolah SMK PGRI Pekanbaru. Sarana pendidikan di SMK PGRI Pekanbaru sudah memadai, ada perpustakaan, kantin, musholla dan lain-lain sebagainya".

Dari hasil wawancara peneliti terhadap Drs. Shofrudin AS selaku Kepala Sekolah SMK PGRI Pekanbaru, maka dapat peneliti mengambil kesimpulan bahwa kompetensi pedagogik guru dalam melaksanakan Standar Proses Kurikulum PAI 2013 Edisi Reivisi di SMK PGRI Pekanbaru dipengaruhi oleh beberapa hal, yaitu: 1) latar belakang pendidikan guru; 2) pengalaman guru dalam mengajar; 3) kesehatan guru; 4) penghasilan guru; 5) sarana pendidikan; 6) disiplin dalam bekerja; dan 7) pengawasan sekolah.

\section{SIMPULAN DAN SARAN Simpulan}

Berdasarkan hasil penelitian ini dapat disimpulkan bahwa kompetensi pedagogik guru dalam melaksanakan Standar Proses kurikulum PAI 2013 Edisi Revisi di SMK PGRI Pekanbaru tergolong "Baik". Hal ini dapat dilihat dari hasil angket yang menunjukkan $80 \%$ dan tes objektif menunujukkan angka $80 \%$, berada diantara 61\%-80\%. Adapun faktor-faktor yang mempengaruhi kompetensi pedagogik guru dalam melaksanakan Standar Proses kurikulum PAI 2013 Edisi Revisi adalah: 1) latar belakang pendidikan guru; 2) pengalaman guru dalam mengajar; 3) kesehatan guru; 4) penghasilan guru; 5) sarana pendidikan; 6) disiplin dalam bekerja; dan 7) pengawasan sekolah.

\section{Saran}

Dari keterangan kesimpulan yang diperoleh, maka peneliti memberikan saran sebagai berikut: 1) Kepala sekolah diharapkan mampu memperhatikan dan memantau kinerja guru didalam mengajar; 2) Guru Pendidikan Agama Islam agar selalu meningkatkan kompetensi pedagogiknya dalam penguasaan kurikulum 2013 PAI Edisi Revisi, sehingga peserta didik dapat memahami pelajaran yang dipelajari dan bisa mengaplikasikannya dalam kehidupan sehari-hari; 3) Peserta didik agar belajar dengan sungguh-sungguh sehingga bisa memahami materi yang dipelajari dan mengaplikasikannya dalam kehidupan sehari-hari; dan 4) Bagi peneliti selanjutnya diharapkan bisa menjadi sumber data atau referensi selanjutnya, kemudian bisa menjadi manfaat bagi pembaca maupun peneliti selanjutnya, dan peneliti selanjutnya diharapkan lebih mempersiapkan diri dalan proses pengambilan dan pengumpulan segala sesuatunya sehingga penelitian dapat dilaksanakan dengan lebih baik. 
80 Instructional Development Journal (IDJ), Vol. 3, No. 2, Agustus 2020, Hal. 75-80

\section{DAFTAR RUJUKAN}

Suhardjono, A. H. (1996). Pedoman Penyusunan Karya Tulis Ilmiah di Bidang Pendidikan dan Angka Kredit Pengembangan Profesi Guru. Jakarta: Depdikbud, Diskdasmen.

Rochman, C., \& Gunawan, H. (2011). Pengembangan Kompetensi Kepribadian Guru: Menjadi Guru yang dicintai dan diteladani oleh Siswa. Bandung: Nuansa Cendekia.

Mulyasa, E. (2005). Menjadi Guru Profesional Menciptakan Pembelajaran Kreatif dan Menyenangkan. Bandung: Remaja Rosdakarya.

Priansa, D.P. (2014). Kinerja dan Profesionalisme Guru. Bandung: Al-fabeta.

Imas, K., \& Sani, B. (2014). Implementasi Kurikulum 2013 Konsep dan Penerapan. Surabaya: Kata Pena.

Purwati, L.E., \& Amri, S. (2013). Panduan Memahami Kurikulum 2013. Jakarta: PT. Prestasi Pustakaraya.

Yunus, A. (2014). Desain Sistem Pembelajaran Dalam Konteks Kurikulum 2013. Bandung: Refika Aditama.

Mulyasa, E. (2013). Pengembangan dan implementasi kurikulum 2013. Jakarat: PT Remaja Rosdakarya.

Syah, H. (2010). Pengantar Umum Metodologi Penelitian Pendidikan Pendekatan Verivikatif. Pekanbaru: Suska Pres.

Sugiyono. (2008). Metode Penelitian Pendidikan:(Pendekatan Kuantitatif, Kualitatif dan R $\mathcal{E}$ D). Bandung: Alfabeta.

Sunariah, K., \& dan Kasmadi, N. (2014). Panduan Modern Penelitian Kuantitatif. Bandung: Alfabeta.

Darwis, A. (2015). Metode Penelitian Pendidikan Islam: Pengembangan Ilmu Berparadigma Islami. Lembaga Penelitian dan Pengabdian Masyarakat, Universitas Islam Negeri Sultan Syarif Kasim Riau. 